\title{
CRIME, ESTADO AUTORITÁRIO E JUSTIÇA DE TRANSIÇÃO: \\ CONTEXTUALIZAÇÃO CONCEITUAL
}

CRIME, AUTHORITARIAN STATE AND TRANSITIONAL JUSTICE: CONCEPTUAL CONTEXT

RESUMO: O presente artigo debate os conceitos de crime úteis ao contexto do Estado autoritário e da justiça de transição. Para tal, aborda a tipologia criminal na perspectiva da dogmática penal clássica, comparando seus desdobramentos teóricos nos regimes autoritários e democráticos. Tendo por objetivo esclarecer os conceitos de crimes comuns, políticos, de Estado e de lesa humanidade no contexto das teorias sobre a justiça de transição, busca traçar as pertinentes diferenciações conceituais entre eles, tendo em vista, igualmente, a conjuntura justransicional brasileira a respeito.

Palavras-chave: Estado autoritário. Justiça de transição. Crimes comuns e políticos. Crimes contra a humanidade. Crimes de Estado.
ABSTRACT: This paper discusses the useful concepts of crime in the context of authoritarian State and transitional justice. So, it works the typology of crimes in the classic criminal theory, comparing its theoretical development in the authoritarian and democratic regimes. Its objective is to explain the concepts of common crimes, political crimes, State's crimes and crimes against humanity in the context of theories of transitional justice, and makes conceptual distinctions between them, observing, in the same way, the situation of Brazilian transitional justice.

Keywords: Authoritarian State. Transitional Justice. Common and political crimes. Crimes against humanity. State's crimes.

\footnotetext{
${ }^{1}$ Professor Associado da Faculdade de Direito do Recife/Universidade Federal de Pernambuco (Departamento de Direito Público Geral e Processual). Disciplina: Direito Constitucional. Doutor em Direito pela UFPE/Universidade de Coimbra-Portugal (PDEE).
} 
Acorda amor

Que o bicho é brabo e não sossega

Se você corre o bicho pega

Se fica não sei não

Atenção

Não demora

Dia desses chega a sua hora Não discuta à toa não reclame

Clame, chame lá, chame, chame

Chame o ladrão, chame o ladrão, chame o ladrão.

(Chico Buarque, Acorda amor)

\section{INTRODUÇÃO}

O advento da democracia como regime político após período autoritário não faz superados aprioristicamente os problemas decorrentes da atuação dos agentes estatais durante o regime de exceção. Neste, precisamente pelo seu caráter autoritário, as graves violações de direitos humanos são chanceladas ou toleradas pelas autoridades oficiais se sua finalidade é a manutenção dos grupos que governam o Estado no momento de seu cometimento.

Em razão disso, são confusos os limites e as possibilidades da configuração de determinados atos como criminosos. Afinal, o que é crime no Estado autoritário? Como diferenciar a atividade oposicionista legítima de atos atentatórios e violentos contrários ao Estado? Será que estes últimos seriam ilegítimos a priori diante da impossibilidade de enfrentamento político no quadro das instituições regulares? E os crimes cometidos pelos agentes do Estado em favor deste último, como poderiam ser classificados? Também seriam políticos, resvalariam à criminalidade comum ou sofreriam alguma classificação distinta, como, p. ex., a de crimes contra a humanidade?

Este breve ensaio tem por objetivo debater essas possibilidades conceituais tendo em vista o ambiente do Estado autoritário e a justiça de transição no período pósautoritarismo. A conformação teórica da justiça de transição parece exigir uma configuração diferenciada da dogmática penal nesses contextos e seu ponto de partida é, inequivocamente, a razoável e necessária precisão conceitual no atual estado da arte do problema. 
Para tal objetivo, lança-se mão da pesquisa na doutrina consagrada pertinente aliada às decisões citadas e/ou comentadas a partir de sua importância paradigmática para a discussão, notadamente da Corte Interamericana de Direitos Humanos e do Supremo Tribunal Federal, cuja consulta foi realizada diretamente nos sites dos referidos órgãos julgadores, que disponibilizam as decisões referidas neste trabalho na íntegra.

\section{TIPOLOGIA CRIMINAL E ESTADO AUTORITÁRIO}

A alegoria realista da canção de Chico Buarque consegue captar algo que muitas vezes longos tratados científicos temáticos não fazem: a ambiguidade das situações de criminalidade em Estados autoritários. Nestes, não se sabe se é melhor chamar a polícia ou o "ladrão", como na letra da canção. Se o Estado se guia pela afirmação de sua autoridade sem os limites decorrentes do binômio democracia-direitos humanos/fundamentais, a figura do criminoso torna-se ambígua a tal ponto que o bandido/terrorista de ontem pode ser o herói de hoje, bem como o agente estatal repressor, herói do regime, pode ser, $a$ posteriori, o criminoso.

A ideia do que seja crime e de quem seja criminoso varia profundamente ao longo da História. Insurretos tidos por bandidos em determinados contextos viram heróis em reflexões posteriores acerca de fatos históricos. O contrário também se verifica.

Longe das sofisticações criminológicas contemporâneas, pode-se ver a repressão a escravos na Antiguidade como lugar comum da aplicação da lei, não raro com condenações à morte dos mesmos. Aqueles vistos como ameaças aos monarcas egípcios, hebraicos e romanos eram igualmente tidos por criminosos, cujo exemplo mais conhecido no ocidente é o do próprio fundador do cristianismo. Não foi diferente o tratamento dos reinos cristãos medievais em relação às "bruxas" condenadas por heresia e sacrilégio ou dos reis absolutistas em relação aos inimigos do reino.

Não é minha pretensão aqui fazer incursões históricas do tipo "falar do Código de Hamurabi” ${ }^{2}$ ou traçar análises criminológicas aprofundadas sobre essas variações de tipologia criminal. A pretensão é apenas de demonstrar a profunda ambiguidade dos

\footnotetext{
${ }^{2}$ Dificilmente se pode esquecer do célebre e instigante texto de Luciano Oliveira, intitulado "Não fale do Código de Hamurábi! A pesquisa sócio-jurídica na pós-graduação em direito” (OLIVEIRA, 2003, passim).
} 
conceitos de crime e de criminoso em relação aos diversos sistemas penais, ambiguidade não completamente eliminada na modernidade.

É inequívoco que a modernidade traça uma redução da complexidade em termos de teoria do crime e do autor do fato punível. Se antes prevaleciam certas horizontalidade e descentralização no poder de punir condutas tidas por socialmente indesejáveis, o direito penal moderno confia a reação ao crime aos técnicos jurídicos e ao aparelho burocrático do Estado, verticalizando e centralizando a justiça penal e trazendo consigo conceitos como o de monopólio estatal da violência e de ordenação racional do poder punitivo. 0 Estado democrático liberal agrega ainda paradigmas como o da legalidade e das garantias penais e processuais penais, voltadas essencialmente para a limitação do poder punitivo desse mesmo Estado (BATISTA, 2011, p. 1).

Se o Estado possui o monopólio da sanção jurídica, esse mesmo Estado se autolimita através da deliberação democrática acerca de quais condutas devem ser puníveis, considerando os parlamentos e poderes legislativos como representantes da vontade popular em avaliar quais atos seriam socialmente desvaliosos a ponto de receberem uma reprimenda de caráter penal, associando tal ato a uma sanção legal de maior gravidade, que seria precisamente a sanção criminal, apontando aqui para um conceito material de delito, tido por autores de renome como neoclássico (WARAT, 1994, p. 171; BITTENCOURT, 2000, p. 140-141; NUCCI, 2007, p. 115).

Não interessa, para as limitadas pretensões deste trabalho, analisar em termos de teoria penal os vários conceitos estruturais do crime. O ponto de partida para debater os crimes cujos conceitos interessam a este ensaio será o conceito analítico de crime, que vê este como um fato típico, antijurídico e culpável, sem afirmá-lo como o melhor dos conceitos, mas apenas como o aparentemente mais aceito por penalistas consagrados (BITTENCOURT, 2000, p. 142-143; NUCCI, 2007, p. 119-121).

Como estabelecer fatos como crimes depende de sua caracterização legal como tais, remontando ao princípio da legalidade penal, tal atividade tende a ser significativamente relativizada quando o sistema de freios e contrapesos próprio da modernidade resta prejudicado, em casos nos quais outros poderes, mais frequentemente o poder executivo, tomam para si essas funções, explícita ou implicitamente. Se a função 
legislativa criminal passa do poder legislativo ao executivo, há historicamente uma maior criminalização de atos políticos contrários aos que detêm o poder, não obstante essa possibilidade não possa ser completamente descartada em democracias nas quais o poder legislativo não possua razoável autonomia deliberativa concreta.

Como a legalidade penal é fundamento do sistema penal moderno, se a lei não provém do poder legitimado para fazê-la, mas do próprio executor das mesmas, os perigos da criminalização de condutas de oposição política são reais e frequentes. E a possibilidade do cometimento de crimes pelos próprios agentes do Estado para manutenção dessa situação de poder faz surgir a real possibilidade de ocorrerem os chamados "crimes de Estado", bem como dos potencialmente presentes "crimes contra a humanidade", conceito este associado especialmente ao desenvolvimento do direito internacional pós-2 Guerra.

Aprioristicamente, não é impossível a ocorrência de crimes políticos, de Estado e de lesa humanidade no Estado democrático. Entretanto, o próprio sistema de freios e contrapesos pode ensejar uma atuação estatal de veemente coibição desses crimes, especialmente na utilização dos mecanismos de direito penal para sua punição.

Mas quando eles ocorrem em um Estado autoritário sob um regime de exceção e salvo no caso dos crimes políticos - quando eles são cometidos em favor desse mesmo regime, a sua punibilidade resta enfraquecida, quando não completamente impossibilitada. Seria um contrassenso lógico os detentores do poder político punirem atos daqueles que o fazem precisamente para a continuidade de tais relações de poder, ainda que a legislação do país em questão preveja tais atos como típicos, antijurídicos e culpáveis/puníveis. A punibilidade desses atos só é plausível quando do advento da democracia como regime político em substituição ao regime de exceção. E as bases para a mesma estão na justiça de transição a partir de demandas internas e/ou internacionais envolvendo os referidos atos. ${ }^{3}$

\footnotetext{
${ }^{3}$ Em outra ocasião (GALINDO, 2015, p. 101), dada sua abrangência, utilizei as definições traçadas por Louis Bickford para a justiça de transição e seus conceitos correlatos, que servem igualmente para os objetivos deste ensaio: "Em linhas gerais, a definição de Louis Bickford sobre o que vem a ser a justiça de transição é bastante abrangente. Para o autor, a justiça transicional consiste em um conjunto de medidas consideradas necessárias para a superação de
} 
Considerando principalmente esse contexto autoritário, é necessário precisar o significado das modalidades de crime relevantes para este trabalho, quais sejam, os crimes comuns, políticos, de Estado e contra a humanidade, ressalvando que determinados crimes podem se estender por mais de uma dessas categorias simultaneamente, como será visto adiante.

\section{CRIME E JUSTIÇA DE TRANSIÇÃO}

\subsection{Crimes comuns e crimes políticos}

Em geral, a doutrina penal classifica os crimes comuns em oposição aos denominados crimes próprios. Estes exigem um sujeito ativo especial ou qualificado, ou seja, somente podem ser praticados por determinadas pessoas; podem ser qualidades de fato (ex.: mulher no auto-aborto) ou de direito (ex.: servidor público no peculato e na corrupção passiva). Os crimes comuns, ao contrário, não exigem tal qualificação, podendo ser cometidos por qualquer pessoa (exs.: homicídio, roubo, falsificação etc.) (NUCCl, 2007, p. 125).

Entretanto, para os objetivos deste trabalho, tal distinção não é tão relevante. A contraposição fundamental a ser feita no debate sobre o crime no contexto da justiça de transição em relação ao Estado autoritário é entre o crime comum e o crime político, sendo necessário defini-los, iniciando pelo primeiro tipo.

No contexto de um Estado autoritário, o crime comum não seria algo essencialmente diferente do que é em um Estado democrático. A partir do conceito analítico de crime, podemos defini-lo aqui como o ato típico, antijurídico e

períodos de graves violações a direitos humanos, ocorridas durante conflitos armados (ex.: guerras civis) e/ou regimes autoritários (ditaduras), implicando a adoção de providências com os seguintes objetivos:

- esclarecimento da verdade histórica e judicial, dentre outras coisas com a abertura dos arquivos estatais do período de exceção;

- instituição de espaços de memória (ex.: memorial do Holocausto, na Alemanha), para que as gerações presentes e futuras possam conhecer e compreender a gravidade do que ocorreu no período de exceção;

- reformas institucionais em relação aos serviços de segurança, adequando-os à pauta axiológica do Estado democrático de direito, bem como sedimentando nas instituições públicas uma cultura democrática e humanista;

- reparação dos danos às vítimas (indenizações, reabilitações etc.);

- realização da justiça propriamente dita, com a responsabilização em variados graus dos violadores dos direitos humanos (BICKFORD, 2004, pp. 1046-1047; GREIFF, 2007, p. 26; com ligeiras variações, cf. tb. PORTO, 2009, p. 180181; UPRIMNY; SAFFON, 2010; PIOVESAN, 2011, p. 78; ZANUZO, 2009, p. 67)". 
culpável/punível perpetrado por qualquer pessoa, independentemente de qualificação pessoal, e sem qualquer motivação de natureza política. É o crime em seu entendimento mais trivial, ainda que de um específico senso comum teórico de juristas. ${ }^{4}$

Crimes contra a vida e contra o patrimônio perpetrados com a finalidade de se subtrair dinheiro de alguém para seu próprio benefício ou de assassinar um indivíduo que seja inimigo pessoal do assassino seriam exemplos clássicos de atos que provavelmente serão tipos penais tanto em um Estado autoritário como em um Estado democrático. Atentar contra a vida sem uma justificativa séria ou violar a propriedade alheia por motivo meramente egoístico tendem a ser criminalizados em quase todos os Estados, independentemente dos seus regimes políticos.

Tais atos podem atingir o Estado quando, por exemplo, o patrimônio do mesmo é violado ou um servidor público é assassinado em serviço, mas o simples fato de o Estado sofrer consequências do crime não o desnatura como crime comum. O Estado foi colateralmente atingido, mas a finalidade do ato pode não ser a de subverter a ordem política e social ou destituir o governo ou ainda aparelhar a oposição política de recursos (financeiros ou de outra ordem) para o confronto com o poder estabelecido.

Percebe-se que perquirir sobre os motivos que ensejaram o cometimento dos crimes é essencial para diferenciar crimes comuns e crimes políticos, embora possa se dizer que há atos que, ainda que perpetrados em um contexto de luta política, dificilmente podem ser caracterizados como delitos dessa natureza, a exemplo do estupro e da tortura.

Enquanto a ausência da motivação política é suficiente para caracterizar um crime como comum e negar a ele a qualificação de político, o inverso não é necessariamente verdadeiro, especialmente nos casos de preponderância dos aspectos de crime comum em relação ao político em concursos/conexões de crimes. Nessas situações, embora em termos teóricos o delito ainda possa ser considerado político, isso não afastaria a possibilidade de condenação por crime comum se, diante da conexão delituosa, este seja o principal dos crimes (STF, 1990).

\footnotetext{
${ }^{4}$ Sem pretensões de aprofundamento conceitual acerca da expressão, partimos do conceito exposto por Luis Alberto Warat, quando afirma que "De uma maneira geral, a expressão "senso comum teórico dos juristas" designa as condições implícitas de produção, circulação e consumo das verdades nas diferentes práticas de enunciação e escritura do Direito." (WARAT, 1994, p. 13).
} 
A definição de crime político não é uma tarefa simples, tanto que, no caso brasileiro, a própria Constituição de 1988 se esquivou de defini-lo, não obstante fazer referência a ele em vários dispositivos. Tal tarefa termina por ser desempenhada pela doutrina e pela jurisprudência.

Reafirme-se que a questão da motivação política é o fator fundamental para caracterizar o crime como político, qualquer que seja ele. A ausência dessa motivação o descaracteriza como tal. E, a partir desta consideração, pode-se afirmar que o crime será político quando, tipificado em ato normativo estatal (ainda que não a lei), seja cometido contra o Estado e sua ordem instituída, com a finalidade de atingir o regime político vigente ou de fortalecer movimentos de oposição a este, normalmente clandestinos. Podese acrescentar que tanto a motivação como o bem jurídico violado ou atingido precisam ser de natureza política (MARQUES, 2011, p. 144; STF, 1995).

O conceito descrito pode ser atribuído ao chamado crime político próprio ou puro. Contudo, especialmente relevante para o debate sobre o crime político no Estado autoritário, é a existência do chamado crime político impróprio ou impuro. Aí as situações são mais complexas, pois, na esteira de autores como Manoel Gonçalves Ferreira Filho e Francisco de Assis Toledo, a motivação política estaria presente (o elemento subjetivo do delito), porém, estaria ausente o dano específico a um bem estatal e político (o elemento objetivo do delito) (MENDES; COELHO; BRANCO, 2007, p. 587-592; GALINDO, 2011, p. 243244; STF, 2007).

Ou seja, enquanto no crime político próprio, temos a presença de ambos os elementos do delito, no impróprio, somente o elemento subjetivo ocorre. Na verdade, é o cometimento do crime como um meio de que se vale o agente para realizar um fim ou objetivo político (VELLOSO, 2003, p. 130-131).

Em termos exemplificativos, poderíamos considerar as situações a seguir.

Situação 1: um escritor e dramaturgo, inconformado com a situação política de repressão e perseguição a opositores do regime perpetradas pelos agentes do Estado, utiliza-se do espaço midiático do qual dispõe para fazer severas críticas ao governo e convocar a população a sair às ruas para protestar e pedir a dissolução do governo atual e a convocação de eleições livres. Este cidadão é preso pela polícia do Estado e condenado 
pelos crimes de subversão e incitamento à desordem. Em um caso como este, vê-se caracterizado o crime político próprio, até pelo fato de que este comportamento, normalmente considerado criminoso por regimes de exceção, é normal e corriqueiro nos Estados democráticos, gozando inclusive de proteção constitucional como garantia fundamental.

Situação 2: neste mesmo hipotético Estado autoritário, ativistas políticos de um movimento de resistência à ditadura decidem assaltar um banco privado para angariar recursos para o financiamento das atividades clandestinas do referido movimento com vistas à derrubada do governo. No referido assalto, há troca de tiros com a polícia e seguranças do banco, sendo um destes atingido mortalmente por tiro de um dos membros deste movimento. Em um caso como estes, o crime cometido em princípio seria comum (roubo e homicídio), contudo, diante da motivação política do contexto, há a possibilidade de caracterizá-lo como crime político impróprio, pois embora presente o elemento subjetivo, não houve uma lesão a um bem estatal político, mas à vida e ao patrimônio de particulares, utilizados como meio para o combate ao Estado autoritário, estando, portanto, ausente o elemento objetivo. Somente indiretamente o Estado pode ser atingido por tal delito.

A caracterização desse segundo tipo de crime político é bastante controversa em termos concretos. Se, por um lado, não é possível traçar uma equivalência entre um sequestrador que faz de sua vítima moeda de troca pela libertação de prisioneiros políticos e outro que sequestra com a mera finalidade de subtrair patrimônio da família da vítima, por outro, há o perigo de, ao se caracterizar atos desse tipo como crimes políticos, conceder verdadeiras "cartas brancas" para o cometimento de crimes comuns travestidos de políticos. A linha limítrofe entre o crime comum e o crime político impróprio é frequentemente obscura e imprecisa, como ocorreu nos célebres debates no STF sobre a Extradição do ex-ativista político italiano Cesare Battisti (STF, 2009).

O Caso Battisti é emblemático como caracterizador da dificuldade de se traçar a linha limítrofe entre a criminalidade comum e a política imprópria. Poucas vezes a Corte suprema brasileira esteve tão dividida. 
A Itália nos anos 70 do século XX já era um Estado democrático há mais de 30 anos. Contudo, a infiltração dos diversos segmentos mafiosos nas entranhas do Estado e seu consequente domínio político, aliada à presença de herdeiros políticos do fascismo, fez com que muitos grupos armados de extrema esquerda surgissem naquela década, sendo as Brigadas Vermelhas o mais célebre. Isso também ocorreu na então Alemanha Ocidental com o Grupo Baader-Meinhof/Fração do Exército Vermelho (RAF - Rote Armee Fraktion).

Pois bem. Cesare Battisti fazia parte de um desses grupos italianos, no caso o PAC (Proletários Armados pelo Comunismo). Grupo de pouca importância naquele contexto, perpetrou, contudo, alguns atos de ataque ao Estado italiano e crimes aparentemente políticos impróprios. Segundo as decisões proferidas pelos tribunais italianos, Battisti esteve envolvido em quatro homicídios cometidos no contexto da luta política do PAC. Delatado por um dos membros do próprio PAC, foi condenado à revelia, embora supostamente teve oportunidade de se defender e preferiu evadir-se do território italiano. O ex-ativista nega a participação nos crimes, embora essa questão não seja tão relevante no contexto da decisão do STF.

Dentre os mortos, um policial e um carcereiro. Em princípio, parece ser um acerto de contas, tendo ocorrido também o homicídio de um açougueiro que se recusara a colaborar com a organização. Ou seja, indicativos de crime comum.

Contudo, as condenações utilizam a dura legislação dos chamados "anos de chumbo" italianos combinada com a legislação penal típica. Não obstante serem um Estado democrático, durante esse período foi editada legislação de exceção (as denominadas "Leis Cossiga") para o combate à subversão e ao terrorismo. A pena é a de prisão perpétua e a exploração do caso pelo governo italiano, inclusive com a frequente referência a Battisti como "terrorista", embora não tenha sido formalmente condenado por esse crime, expõe a possibilidade de perseguição política naquele Estado, apesar do regime político democrático em vigor.

Diante de um contexto tão conturbado, a Corte ficou dividida e os debates foram acalorados, sendo possível vislumbrar argumentos bastante consistentes, tanto caracterizadores da prevalência da criminalidade comum sobre a política, como no sentido inverso, da prevalência dos fatores políticos nos crimes cometidos. Em verdade, a divisão 
já existia no próprio CONARE (Comissão Nacional para os Refugiados), órgão do Ministério da Justiça responsável pela concessão de refúgio político. Este órgão decidiu negar o refúgio pelo apertado escore de três votos contrários e dois favoráveis à concessão. O exativista recorreu ao Ministro da Justiça, à época Tarso Genro, que, utilizando competência recursal decorrente da Lei 9474/1997, art. 29, reformou a decisão do órgão ministerial, concedendo o refúgio.

Depois de muitas idas e vindas, o STF terminou por decidir favoravelmente à extradição de Cesare Battisti pelo apertado placar de cinco votos favoráveis e quatro contrários $^{5}$ e o italiano só não foi extraditado para a Itália em virtude da negativa do Presidente da República (à época Luís Inácio Lula da Silva) em encaminhá-la, utilizando-se da prerrogativa de chefe de Estado de decidir politicamente pela não extradição.

Foi um dos casos mais controversos da história do Tribunal e demonstra o quanto definir os limites entre essas duas formas de criminalidade pode ser difícil.

Todavia, como será visto no item seguinte, em termos teóricos, não é possível confundir crime político com os crimes cometidos pelos próprios agentes estatais em favor da manutenção do regime político vigente. Crime político é, direta ou indiretamente, um crime contra o Estado e contra sua ordem vigente (VELLOSO, 2003, p. 130-131).

\subsection{Crimes de Estado e crimes contra a humanidade}

Em relação ao período de exceção e à justiça de transição posterior ao mesmo, os crimes de Estado e os crimes contra a humanidade ganham uma importância muito mais significativa, dentre outras coisas, pela tendência natural à impunidade em relação a eles, diferentemente do que ocorre com os crimes comuns e políticos cometidos pelos cidadãos em geral, normalmente já sancionados pelo próprio Estado autoritário, frequentemente com rigor ainda maior do que no Estado democrático.

\footnotetext{
${ }^{5}$ Votaram pelo deferimento da extradição, enxergando os referidos crimes como comuns os Mins. Cézar Peluso (Relator), Carlos Ayres Britto, Ellen Gracie, Gilmar Mendes e Ricardo Lewandowski. Votaram contrariamente ao deferimento, enxergando tais crimes como políticos os Mins. Carmem Lúcia Rocha, Eros Grau, Joaquim Barbosa e Marco Aurélio Mello (Ext. 1085/Itália, Rel. Min. Cézar Peluso, j. 16/12/2009). Um relato bastante interessante do Caso Battisti, não obstante a natural parcialidade do autor, hoje Ministro do STF, mas à época advogado do ex-ativista italiano, está em livro sobre as novas tendências do direito constitucional brasileiro (Barroso: 2013, pp. 447-522).
} 
Em princípio, afasta-se a possibilidade de se confundir tais crimes com os crimes políticos, considerando o caráter antiestatal destes últimos. Também não poderiam entrar na categoria dos crimes comuns em sentido estrito, considerando a especial motivação dos criminosos em questão em colaborar na manutenção de um regime de exceção. Embora configurem em geral a perpetração de atos típicos, antijurídicos e culpáveis/puníveis, a motivação colaboracionista e a tendência à completa ou significativa aniquilação dos inimigos do regime político vigente fazem com que esses delitos não sejam combatidos pelo Estado, nem seus perpetradores processados e punidos; antes, ao contrário, há incentivos (ainda que na maioria das vezes sub-reptícios) por parte do regime ao cometimento mesmo dos crimes em questão, sendo agentes estatais oficiais e/ou colaboradores do Estado os encarregados dessas "tarefas".

Caracterizar um crime como de Estado e de lesa humanidade simultaneamente não é algo raro; ao contrário, é frequente o cometimento de crimes que podem ser classificados nos dois tipos ao mesmo tempo. Entretanto, eles não necessariamente se confundem, cabendo sua distinção conceitual.

Para os limites deste ensaio, podemos definir os crimes de Estado como todos aqueles atos típicos, antijurídicos e culpáveis/puníveis cometidos por agentes estatais ou a serviço do Estado em benefício do regime político em vigor. A tipificação pode ser prevista no direito interno e/ou no direito internacional, o que, dependendo do caso concreto, pode acarretar a punição do agente, ainda que ocorra escusa normativa interna. Isso é especialmente relevante no tratamento desses crimes no contexto do Estado autoritário, muito embora na maioria das vezes eles também sejam tipificados no direito penal interno. O problema maior gira em torno da eficácia dessas normas quanto aos criminosos de Estado, considerando os benefícios oriundos do crime ao regime político existente.

Em percuciente estudo sobre o tema à luz da criminologia crítica de lan Taylor, James Inciardi e Alessandro Baratta, o penalista argentino Raúl Zaffaroni destaca a justificação para o cometimento de tais crimes como um dos mais relevantes problemas para estudos que possam sair da mera crítica pueril e aprofundar a compreensão do fenômeno (ZAFFARONI, 2007, passim). 
Ao longo do século XX e já no século atual, a alegação de que é preciso combater o terrorismo é uma das justificativas mais utilizadas para admitir que os próprios agentes estatais quebrem as regras do Estado de direito em nome da segurança da população. Isso ocorreu até mesmo em democracias sólidas como os EUA e o Reino Unido, admitindo-se que o rule of law pode e deve ser relativizado no combate aos terroristas. Com muito mais frequência e ênfase, os Estados autoritários também se valem da justificativa de combate ao terrorismo para impor aos cidadãos medidas severamente restritivas à liberdade e quebrar suas próprias regras jurídicas, sendo lenientes com o cometimento de crimes pelo próprio Estado, desde que com aquela justificativa (ZAFFARONI, 2007, p. 21-22).

Há uma dificuldade inicial na própria definição do que seja terrorismo, algo extremamente controverso e obscuro, que faz com que possam ser situados retoricamente nesse rol classificatório desde atentados de destruição em massa, como os ataques ao World Trade Center nova-iorquino (as famosas "torres gêmeas") e ao metrô madrilenho na década passada, até atos de desobediência civil generalizada como dos tibetanos partidários do Dalai Lama em relação ao domínio chinês em seu país e dos indianos liderados por Mahatma Gandhi quanto ao domínio britânico. Em uma zona de penumbra, são classificados como terroristas atos violentos diversos praticados por organizações de resistência a regimes políticos diversos, a exemplo do ANC (African National Congress) na África do Sul dos anos do apartheid, do IRA (Irish Republican Army) na Irlanda/Reino Unido, do ETA (Euskadi Ta Akatasuna - Pátria Basca e Liberdade) na Espanha, das Brigadas Vermelhas na Itália, da RAF (Rotes Armee Fraktion - Fração do Exército Vermelho)/Baader-Meinhof na Alemanha, dos judeus da resistência do Gueto de Varsóvia, da Resistência Francesa na 2ạ Guerra, bem como de movimentos de guerrilha como os Montoneros na Argentina e as várias organizações de luta armada contra a ditadura no Brasil (VPR, VAR-Palmares, ALN e outras). Todas estas, com maior ou menor frequência, foram chamadas de organizações terroristas e seus membros qualificados como tal, a exemplo da ex-Presidente do Brasil, Dilma Roussef, militante da VAR-Palmares à época dos chamados "anos de chumbo" brasileiros. 
A profunda ambiguidade acerca do significado de terrorismo, destacada também por autores como Sarah Pellet ${ }^{6}$, já demonstra que se trata de conceito vago e impreciso o suficiente para ser utilizado justificada ou injustificadamente na tomada de medidas repressivas duras e cerceadoras de direitos e liberdades constitucionais. Mais do que isso, no caso dos Estados autoritários, é largamente utilizado para justificar os ditos crimes de Estado, cometidos em nome de um igualmente vago bem maior, a "paz social" ou a "segurança pública", até mesmo a vida e a liberdade, por paradoxal que possa parecer.

Não é objetivo deste trabalho aprofundar conceitualmente a questão do terrorismo, mas apenas tentar elucidar as razões pelas quais os crimes de Estado são socialmente tolerados, não obstante serem por vezes uma quebra da legalidade do próprio Estado autoritário. É aí que alguns propõem a noção de que o terrorismo também pode ser incluído nesse rol de crimes, configurando o que se denomina de "terrorismo de Estado" (LITVACHKY, 2007). Se se admite que o Estado pode ser criminoso, não é absurdo conceber a possibilidade de que ele também possa ser terrorista.

Em verdade, vários crimes comuns, como o homicídio, o sequestro, o aprisionamento ilegal e abusivo, a tortura e muitos outros, podem ser cometidos com a finalidade de beneficiar o regime político vigente, dirigindo esses atos contra os inimigos do mesmo. No Estado democrático, os sistemas de freios e contrapesos e os controles democráticos tendem a prevenir e/ou enfrentar com mais eficácia esses crimes, ao passo que no Estado autoritário, a tendência é tolerá-los e não poucas vezes incentivá-los. Esses crimes tendem a serem vistos pelo poder dominante como excessos ou consequências indesejadas, porém inevitáveis diante da situação de combate à subversão e ao terrorismo.

Para Zaffaroni, é relativamente frequente o criminoso de Estado se apresentar em tal contexto como alguém predestinado a superar crises de valores, a reafirmar valores nacionais, a defender a moral pública e a família, a sanear os costumes etc. "El criminal de

\footnotetext{
${ }^{6}$ Para o aprofundamento sobre o debate conceitual do termo "terrorismo", considero bastante esclarecedor o trabalho da Professora francesa publicado no Brasil. A noção geral de terrorismo aponta para a "ameaça vagamente percebida, pouco familiar e largamente imprevisível" que espalha o medo e a ansiedade extremada em uma dada sociedade (PELLET, 2003, p. 10). Na mesma coletânea, cf. tb. Sampaio (2003). Ainda o debate conceitual em Basso (2004, p. 208-211).
} 
Estado casi siempre se presenta como un moralista y como un verdadero líder moral" (ZAFFARONI, 2007, p. 26).

Crimes contra a humanidade, por sua vez, são inúmeras vezes também crimes de Estado. Entretanto, é de se afastar uma completa identificação entre uns e outros pelas razões que se seguem.

A noção de crimes de lesa humanidade já existia difusamente no direito internacional pelo menos desde a 2a década do século XX. É no final da Primeira Guerra Mundial que alguns veem essa noção implícita no Tratado de Sèvres (1920), ocasião em que se condenou o massacre da minoria armênia pelo Império Turco Otomano (WEICHERT; FÁVERO: 2009, p. 517-518). Em verdade, a condenação ao massacre dos armênios em que se referiu expressamente a "crimes contra a humanidade e a civilização" foi anterior ao Tratado em questão, tendo sido feita em uma nota conjunta assinada pela França, Reino Unido e Rússia, em 1915 (MELLO, 2004, p. 972).

Mas é reconhecido que, em termos expressos, somente após o final da 2a Guerra Mundial, com a instalação do Tribunal Militar Internacional de Nuremberg, essa noção deixa de ser um conceito diluído no direito internacional consuetudinário para se tornar expressa no Estatuto do Tribunal que, em seu art. 6으, c, afirma que esses crimes são o homicídio, o extermínio, a escravidão e outros atos desumanos cometidos contra a população civil antes ou durante a guerra ou ainda perseguições baseadas em critérios raciais, políticos e religiosos para a execução de crimes ou em conexão com crimes de competência do referido Tribunal, independentemente de terem sido ou não praticados em violação do direito interno do país onde foram perpetrados (PIOVESAN, 2006, p. 34; WEICHERT; FÁVERO, 2009, p. 518; LOPES, 1999, p. 500; GALINDO, 2011, p. 225; GAETA, 2004, p. 255). ${ }^{7}$

\footnotetext{
7 "Artículo 6. El Tribunal establecido por el Acuerdo aludido en el Artículo 1 del presente para el enjuiciamiento y condena de los principales criminales de guerra del Eje Europeo estará facultado para juzgar y condenar a aquellas personas que, actuando en defensa de los intereses de los países del Eje Europeo, cometieron los delitos que constan a continuación, ya fuera individualmente o como miembros de organizaciones:

Cualesquiera de los actos que constan a continuación son crímenes que recaen bajo la competencia del Tribunal respecto de los cuales habrá responsabilidad personal:

[...] c) CRIMENES CONTRA LA HUMANIDAD: A saber, el asesinato, la exterminación, esclavización, deportación y otros actos inhumanos cometidos contra población civil antes de la guerra o durante la misma; la persecución por motivos
} 
Percebe-se inicialmente uma indefinição conceitual que permite uma manipulação da noção de crimes de lesa humanidade em desfavor dos criminosos nazistas que foram réus nos julgamentos do pós-Guerra. Aliado a isso, temos a questão de serem tais crimes estabelecidos post facto, ou seja, sem a garantia clássica da irretroatividade in malam parte da lei penal, o que suscitou e suscita ainda muitos debates sobre esse "defeito de fábrica" de tal noção.

Apesar desses problemas do Juízo de Nuremberg, é certo, porém, que a inconclusiva definição do Estatuto inspirou uma nova posição do indivíduo no âmbito internacional. Se antes eram bem conhecidos juridicamente apenas os chamados crimes de guerra e desconhecida a ideia de crimes de lesa humanidade ${ }^{8}$, essa categoria inaugurada pelo Estatuto do Tribunal traz a concreta possibilidade de estipulação de direitos e deveres aos indivíduos diretamente pelo direito das gentes sem escusas de direito nacional e ainda que sejam agentes do Estado agindo em nome deste (DINH; DAILLIER; PELLET, 1999, p. 586; FRULLI, 2004, p. 272-273). É perspectiva que remonta a Hans Kelsen que, ainda em 1944, quando publica nos EUA a obra "A paz por meio do direito" (sua "utopia realista" segundo Massimo La Torre e Cristina García Pascual), prevê exatamente essa situação de responsabilização individual fundamentada no jus cogens internacional, com várias implicações e antevisões para o Pós-Guerra (KELSEN, 2003, passim).

É posição que gradativamente ganhou contornos mais definidos, sendo reiteradamente afirmada pela legislação positiva internacional universal e regional, pela Comissão de Direito Internacional e Assembleia Geral da ONU, bem como pela jurisprudência dos diversos tribunais internacionais, tanto as Cortes Europeia e Interamericana de Direitos Humanos, como os tribunais penais internacionais ad hoc los mismos, constituyan o no una vulneración de la legislación interna de país donde se perpetraron. Disponível em http://www.ehu.es/ceinik/tratados/7TRATADOSRELATIVOSACRIMENESDEGUERRA/CG73.pdf, acesso: 12/07/2012.

\footnotetext{
${ }^{8}$ Ian Brownlie, Professor da Universidade de Oxford/Reino Unido, estabelece doutrinariamente outra perspectiva, afirmando que "A categoria dos crimes de guerra era, sem dúvida, considerada Direito ortodoxo em 1945, sendo os crimes contra a humanidade, em grande medida, crimes de guerra numa acepção ampla" (BROWNLIE, 1997, p. 518). A ressalva do Professor britânico é plausível no contexto nuremberguiano, contudo destoa da dissociação atual entre crimes de guerra e crimes de lesa humanidade, admitindo que estes podem ser cometidos também em tempos de paz (WEICHERT; FÁVERO: 2009, p. 561-567; PIOVESAN, 2011, p. 73; BELAÚNDE, 2003, passim; Corte Interamericana de Direitos Humanos - Caso Almonacid Arellano/2006 - sentença disponível em www.corteidh.or.cr).
} 
casos da ex-lugoslávia e de Ruanda (TRINDADE, 2004, p. 219-225; BROWNLIE, 1997, p. 585;

DELMAS-MARTY, 2004, p. 64-65).

Esse paradigma termina por se consolidar no art. 7 do Estatuto de Roma que, em 1998 criou o Tribunal Penal Internacional, primeira corte criminal internacional de caráter permanente. ${ }^{9}$ Para os julgamentos a serem realizados nesta Corte, é vinculante o texto abaixo transcrito que, como ocorre com frequência no plano do direito internacional, consolida entendimentos reiterados ao longo da segunda metade do século passado sobre os crimes contra a humanidade. O dispositivo está assim redigido:

1. A los efectos del presente Estatuto, se entenderá por "crimen de lesa humanidad" cualquiera de los actos siguientes cuando se cometa como parte de un ataque generalizado o sistemático contra una población civil y con conocimiento de dicho ataque:

a) Asesinato;

b) Exterminio;

c) Esclavitud;

d) Deportación o traslado forzoso de población;

e) Encarcelación u otra privación grave de la libertad física en violación de normas fundamentales de derecho internacional;

f) Tortura;

g) Violación, esclavitud sexual, prostitución forzada, embarazo forzado, esterilización forzada o cualquier otra forma de violencia sexual de gravedad comparable;

h) Persecución de un grupo o colectividad con identidad propia fundada en motivos políticos, raciales, nacionales, étnicos, culturales, religiosos, de género definido en el párrafo 3, u otros motivos universalmente reconocidos como inaceptables con arreglo al derecho internacional, en conexión con cualquier acto mencionado en el presente párrafo o con cualquier crimen de la competencia de la Corte;

i) Desaparición forzada de personas;

j) El crimen de apartheid;

k) Otros actos inhumanos de carácter similar que causen intencionalmente grandes sufrimientos o atenten gravemente contra la integridad física o la salud mental o física.

2. A los efectos del párrafo 1:

a) Por "ataque contra una población civil" se entenderá una línea de conducta que implique la comisión múltiple de actos mencionados en el párrafo 1 contra una población civil, de conformidad con la política de un Estado o de una organización de cometer ese ataque o para promover esa política;

b) El "exterminio" comprenderá la imposición intencional de condiciones de vida, entre otras, la privación del acceso a alimentos o medicinas, entre otras, encaminadas a causar la destrucción de parte de una población;

c) Por "esclavitud" se entenderá el ejercicio de los atributos del derecho de propiedad sobre una persona, o de algunos de ellos, incluido el ejercicio de esos atributos en el tráfico de personas, en particular mujeres y niños;

\footnotetext{
${ }^{9}$ Em funcionamento desde 2002, a partir da 60a ratificação. Cf. www.un.org/spanish/law/icc.
} 
d) Por "deportación o traslado forzoso de población" se entenderá el desplazamiento forzoso de las personas afectadas, por expulsión u otros actos coactivos, de la zona en que estén legítimamente presentes, sin motivos autorizados por el derecho internacional;

e) Por "tortura" se entenderá causar intencionalmente dolor o sufrimientos graves, ya sean físicos o mentales, a una persona que el acusado tenga bajo su custodia o control; sin embargo, no se entenderá por tortura el dolor o los sufrimientos que se deriven únicamente de sanciones lícitas o que sean consecuencia normal o fortuita de ellas;

f) Por "embarazo forzado" se entenderá el confinamiento ilícito de una mujer a la que se ha dejado embarazada por la fuerza, con la intención de modificar la composición étnica de una población o de cometer otras violaciones graves del derecho internacional. En modo alguno se entenderá que esta definición afecta a las normas de derecho interno relativas al embarazo;

g) Por "persecución" se entenderá la privación intencional y grave de derechos fundamentales en contravención del derecho internacional en razón de la identidad del grupo o de la colectividad;

h) Por "el crimen de apartheid" se entenderán los actos inhumanos de carácter similar a los mencionados en el párrafo 1 cometidos en el contexto de un régimen institucionalizado de opresión y dominación sistemáticas de un grupo racial sobre uno o más grupos raciales y con la intención de mantener ese régimen;

i) Por "desaparición forzada de personas" se entenderá la aprehensión, la detención o el secuestro de personas por un Estado o una organización política, o con su autorización, apoyo o aquiescencia, seguido de la negativa a admitir tal privación de libertad o dar información sobre la suerte o el paradero de esas personas, con la intención de dejarlas fuera del amparo de la ley por un período prolongado.

3. A los efectos del presente Estatuto se entenderá que el término "género" se refiere a los dos sexos, masculino y femenino, en el contexto de la sociedad. El término "género" no tendrá más acepción que la que antecede. ${ }^{10}$

De certo modo, o texto normativo do Estatuto do TPI consolida e sintetiza os entendimentos contemporâneos sobre o conteúdo dos crimes de lesa humanidade, atualizando e complementando o legado de Nuremberg (TEITEL, 2003, p. 23).

Do texto podem-se inferir algumas conclusões provisórias.

Os crimes contra a humanidade não se confundem com os crimes de guerra, pois os atos típicos, ilícitos e culpáveis/puníveis previstos são possíveis em tempos de guerra e de paz. Aliás, em outros trabalhos de minha autoria publicados e aqui citados, a análise é fundamentalmente relacionada com experiências de justiça transicional ocorridas em períodos pós-autoritários sem guerras declaradas durante os respectivos regimes de 
exceção, salvo no caso das referências à Alemanha nazista em que as duas situações (Estado autoritário e situação de beligerância) estiveram simultaneamente presentes.

Eles também não coincidem necessariamente com os crimes de Estado, como se pode perceber. Os crimes de Estado necessitam para sua caracterização da participação direta ou indireta do Estado, algo frequente nos crimes de lesa humanidade, mas não necessário. Esses crimes podem ser cometidos por organizações não estatais: redes fundamentalistas internacionais como a Al Qaeda, de Osama Bin Laden, ou mais recentemente o Estado Islâmico, praticaram assassinatos em massa - atos tidos como terroristas - contra populações civis; organizações racistas como a Ku Klux Klan, nos EUA, praticaram assassinatos, torturas e perseguição contra os negros norte-americanos; os centros de detenção argentinos da última ditadura eram entes não oficiais, embora neste caso específico pode-se afirmar o cometimento de crimes de Estado em virtude da omissão e conivência deste e mesmo da participação de significativa parcela de agentes estatais nos delitos de lesa humanidade perpetrados nos centros clandestinos em questão (GALINDO, 2012, p. 208). Também grupos paramilitares de direita que combateram as guerrilhas na Colômbia, as próprias guerrilhas colombianas como as FARCs e o Sendero Luminoso no Peru, também são organizações acusadas de crimes contra a humanidade.

A maioria dos crimes de lesa humanidade é tipificada também como crimes comuns na legislação penal de Estados democráticos e autoritários. Entretanto, a diferença está justamente na especial qualificação decorrente do contexto de serem os crimes contra a humanidade cometidos "como parte de um ataque generalizado e sistemático contra uma população civil e com conhecimento deste ataque" (Estatuto do TPI, art. 7, 1, caput). Diante da diferença contextual, a prática da tortura como ato isolado em uma delegacia de polícia ou prisão, embora seja crime, não necessariamente é delito de lesa humanidade se a qualificadora do referido tratado internacional não estiver presente, o que pode ter consequências relevantes, por exemplo, no que diz respeito à impossibilidade da prescrição em relação a torturas praticadas durante um regime de exceção e à sua possibilidade diante dos mesmos crimes quando ausente àquela qualificadora.

$E$, por óbvio, dificilmente se enquadrariam os crimes contra a humanidade no rol dos crimes políticos, pois não se tratam em geral de crimes contra o Estado, mas, no 
máximo, contra cidadãos deste mesmo Estado. As exigências do parágrafo 1 do art. 7 do Estatuto do TPI não são de fácil compatibilização com uma conexão com crimes políticos, a não ser em construções hermenêuticas bastante heterodoxas, como aquela realizada pela Corte Suprema brasileira na decisão proferida na ADPF 153 (interpretação da Lei da Anistia), decisão ora objeto de questionamento através de embargos de declaração, considerando a posterior Sentença da Corte Interamericana de Direitos Humanos em sentido diametralmente oposto. ${ }^{11}$

\section{CONCLUSÕES}

As reflexões aqui expostas passam pela necessidade de aprofundamento da compreensão dos conceitos em jogo quando do importante debate acerca da justiça de transição, enfrentado com maior ênfase no Brasil bem tardiamente, já que a transição política iniciada em fins dos anos 70 do século passado não permitiu até bem pouco tempo atrás um debate mais denso acerca das medidas transicionais necessárias e seus formatos. E um dos problemas relevantes é precisamente o problema conceitual.

A decisão proferida na ADPF 153 pelo Supremo Tribunal Federal permanece na tradicional trilha interpretativa da Lei da Anistia de 1979 de se considerar políticos por conexão os crimes de lesa humanidade praticados pelos agentes do regime de exceção quando, como demonstrado, mesmo do ponto de vista da dogmática penal clássica, é algo dificilmente defensável. Foi necessária a admissão por alguns dos Ministros do STF de que se tratava de uma conexão sui generis, incompatível de fato com o conceito clássico oriundo do direito penal.

Há aqui problemas com o alargamento do conceito de crime político por conexão, o que pode estipular como políticos delitos de natureza comum sem relação com a atuação política de resistência ao poder estabelecido ou, ainda mais grave, o cometimento de crimes de lesa humanidade tipificados desde o Tribunal de Nuremberg como tais e

\footnotetext{
${ }^{11}$ Destaque-se a observação de Albuquerque Mello, abordando a proibição constitucional brasileira de extraditar estrangeiros por crimes políticos: "Não são equiparados aos criminosos políticos os criminosos de guerra, os autores de genocídio, ou melhor, os autores de crimes contra a humanidade e os dos crimes contra a paz. Pode-se acrescentar ainda, os autores das denominadas infrações graves do Direito Internacional Humanitário. Tais criminosos são passíveis de extradição, porque a tais crimes não se aplica o conceito de criminalidade relativa; pelo contrário, eles são violações de normas internacionais" (MELLO, 2006, p. 221, grifos do autor).
} 
amplamente aceitos pelos ordenamentos jurídicos estatais (inclusive o nosso), também com tal qualificativo, neste caso não cumprindo sequer o pressuposto básico de um delito contrário ao Estado e ao seu governo, mas, diversamente, sendo perpetrado em favor dos mesmos e da manutenção do poder político estabelecido.

No primeiro caso, temos situações como a do ex-ativista político italiano Cesare Battisti, em que a alegação pelo caráter político da persecução penal em razão das condenações que o mesmo sofreu na Itália por quatro homicídios supostamente cometidos por razões políticas foi afastada pela maioria dos Ministros do STF, que consideraram preponderantes os aspectos de criminalidade comum nos delitos em questão e autorizaram a extradição requerida pelo Estado italiano.

No segundo caso, curiosamente, boa parte dos Ministros que rechaçaram o caráter político dos crimes de Battisti, trazendo vasta e consistente argumentação nesse sentido, utilizaram critérios aparentemente díspares no que diz respeito à caracterização dos crimes cometidos pelos agentes brasileiros da repressão política à época da ditadura militar brasileira como crimes políticos conexos, não obstante seu cometimento ter sido por agentes do próprio Estado e em favor deste. Especialmente os votos dos Mins. Cézar Peluso, Ellen Gracie e Gilmar Mendes são substancialmente dissonantes entre si quando comparadas as linhas argumentativas desenvolvidas nos dois julgados por cada um dos julgadores (Ext 1085/Itália e ADPF 153).

Esperava-se que os Embargos de Declaração interpostos pelo Conselho Federal da OAB na ADPF 153 após a Sentença da Corte Interamericana de Direitos Humanos (que entendeu pela incompatibilidade dessa interpretação com a Convenção Americana de Direitos Humanos), assim como a nova ADPF 320, proposta pelo Partido Socialismo e Liberdade (PSOL), pudessem servir quando de sua apreciação para que o Tribunal aclare tais discrepâncias conceituais e, por consequência, o alcance das decisões do STF e da Corte IDH a respeito, aparentemente incompatíveis entre si.

Contudo, em recente decisão na Extradição 1362 (j. 09/11/2016), ${ }^{12}$ o STF negou a extradição de um suposto criminoso de lesa humanidade para a República Argentina,

\footnotetext{
${ }^{12} \mathrm{O}$ indeferimento da Extradição solicitada pelo Estado argentino se deu por apertado escore. Decidiram pela denegação os Mins. Celso de Mello, Dias Toffoli, Gilmar Mendes, Luiz Fux, Marco Aurélio Mello e Teori Zavascki, sendo
} 
considerando ter ocorrido a prescrição dos crimes, não obstante a Sentença da Corte IDH no Caso Gomes Lund/“Guerrilha do Araguaia”, assim como sua reiterada jurisprudência, serem uníssonas no sentido da imprescritibilidade de tais crimes. Aliado a isso, o fato de estarem os Embargos Declaratórios na ADPF 153 há mais de 4 anos pendentes de decisão, assim como a ADPF 320, mesmo após Parecer do Procurador-Geral da República pelo seu provimento, estar há mais de um ano sem qualquer movimentação processual, indicam ser pouco provável que a Corte Suprema brasileira ajuste sua jurisprudência ao que o Brasil formalmente se obrigou desde 1998, permanecendo o Estado brasileiro em situação de descumprimento da Sentença da Corte IDH, bem como incorrendo em situação de responsabilização internacional em razão de tais decisões do STF.

\section{REFERÊNCIAS}

BARROSO, Luís Roberto. O novo direito constitucional brasileiro (contribuições para a construção teórica e prática da jurisdição constitucional no Brasil). Belo Horizonte: Fórum. 2013.

BASSO, Maristela. Terrorismo e Violação dos Direitos Humanos: Crise e Necessidade de Revisão do Direito Internacional. In: Wagner MENEZES (org.). 0 direito internacional e o direito brasileiro - homenagem a José Francisco Rezek. Ijuí: Unijuí, 2004. p. 205-224.

BATISTA, Gustavo Barbosa de Mesquita. Mercantilização do sistema penal brasileiro. Recife: Tese de Doutorado/UFPE, 2011.

BELAÚNDE, Domingo García. Amnistía y Derechos Humanos (A Propósito de la Sentencia de la Corte Interamericana de Derechos Humanos en el Caso "Barrios Altos"). In: GRAU, Eros Roberto; CUNHA, Sérgio Sérvulo da. Estudos de Direito Constitucional em Homenagem a José Afonso da Silva. São Paulo: Malheiros, 2003, p. 409-422.

BICKFORD, Louis. Transitional Justice. In: The Encyclopedia of Genocide and Crimes Against Humanity, Macmillan Reference USA, vol. 3, p. 1045-1047, 2004.

BITTENCOURT, Cézar Roberto. Manual de Direito Penal - Parte Geral - Volume 1. 6. ed. São Paulo: Saraiva, 2000.

BROWNLIE, Ian. Princípios de Direito Internacional Público (trad. Maria Manuela Farrajota, Maria João Santos, Victor Richard Stockinger e Patrícia Galvão Teles). Lisboa: Calouste Gulbenkian, 1997.

DELMAS-MARTY, Mireille. Os crimes internacionais podem contribuir para o debate entre universalismo e relativismo de valores? (trad. Sílvio Antunha). In: Antonio CASSESE; 
DELMAS-MARTY, Mireille (orgs.). Crimes Internacionais e Jurisdições Internacionais. Barueri: Manole, 2004. p. 61-72.

DINH, Nguyen Quoc; DAILLIER, Patrick; PELLET, Alain. Direito Internacional Público. Lisboa: Calouste Gulbenkian, 1999.

FRULLI, Micaela. O direito internacional e os obstáculos à implantação de responsabilidade penal para crimes internacionais (trad. Sílvio Antunha). In: Antonio CASSESE; DELMASMARTY, Mireille (orgs.). Crimes Internacionais e Jurisdições Internacionais. Barueri: Manole, 2004. p. 269-328.

GAETA, Paola. As regras internacionais sobre os critérios de competência dos juízes nacionais" (trad. Sílvio Antunha). In: Antonio CASSESE; DELMAS-MARTY, Mireille (orgs.). Crimes Internacionais e Jurisdições Internacionais. Barueri: Manole, 2004. p. 237-268.

GALINDO, Bruno. Constitucionalismo e justiça de transição: em busca de uma metodologia de análise a partir dos conceitos de autoritarismo e democracia. In: Revista da Faculdade de Direito da Universidade Federal de Minas Gerais, Belo Horizonte, n. 67, p. 75-104, 2015.

GALINDO, Bruno. Justiça de transição na América do Sul: Possíveis lições da Argentina e do Chile ao processo constitucional de transição no Brasil. In: FEITOSA, Enoque et al. (orgs.). 0 judiciário e o discurso dos direitos humanos, vol. 2. Recife: Universitária (UFPE), 2012. p. 197-242.

GALINDO, Bruno. Direitos humanos e justiça constitucional transicional: ainda sob(re) as sombras do passado autoritário. In: SILVA, Artur Stamford da (org.). 0 judiciário e o discurso dos direitos humanos. Recife: Universitária/UFPE, 2011. p. 221-264.

GREIFF, Pablo De. La Contribución de la Justicia Transicional a la Construcción y Consolidación de la Democracia. In: BLEEKE, Mô R; CIURLIZZA, Javier; BOLAÑOS-VARGAS, Andrea (orgs.). Memorias - Conference Paper. Serie Enfrentando el Pasado - El Legado de la Verdad: Impacto de la Justicia Transicional en la Construcción de la Democracia en América Latina. Bogotá: ICTJ, 2007. p. 25-35.

KELSEN, Hans. La Paz por Medio del Derecho (trad. Luis Echávarri). Madrid: Trotta, 2003.

LITVACHKY, Paula. La Respuesta Penal a los Crímenes del Terrorismo de Estado en Argentina. . In: BLEEKE, Mô R; CIURLIZZA, Javier; BOLAÑOS-VARGAS, Andrea (orgs.). Memorias - Conference Paper. Serie Enfrentando el Pasado - El Legado de la Verdad: Impacto de la Justicia Transicional en la Construcción de la Democracia en América Latina. Bogotá: ICTJ, 2007. p. 108-117.

LOPES, José Alberto Azeredo. Textos Históricos do Direito e das Relações Internacionais. Porto: Universidade Católica Portuguesa, 1999.

MARQUES, Ivan Luís. O princípio da imprescritibilidade dos crimes contra a humanidade e sua aplicação no Brasil. In: GOMES, Luiz Flávio; MAZZUOLI, Valério de Oliveira (orgs.). Crimes da Ditadura Militar - Uma análise à luz da jurisprudência atual da Corte Interamericana de Direitos Humanos. São Paulo: Revista dos Tribunais, 2011. p. 135-154. 
MELLO, Celso D. de Albuquerque. Curso de direito internacional público, vol. II. 15. ed. Rio de Janeiro: Renovar, 2004.

MELLO, Celso D. de Albuquerque. Extradição: Algumas observações. In: TIBÚRCIO, Carmem; BARROSO, Luís Roberto (orgs.). O direito internacional contemporâneo: estudos em homenagem ao professor Jacob Dolinger. Rio de Janeiro: Renovar, 2006. p. 195-228.

MENDES, Gilmar Ferreira; COELHO, Inocêncio Mártires; BRANCO, Paulo Gustavo Gonet. Curso de Direito Constitucional. São Paulo: Saraiva, 2007.

NUCCl, Guilherme de Souza. Código Penal Comentado. 7. ed. São Paulo: Revista dos Tribunais, 2007.

OLIVEIRA, Luciano. Não fale do Código de Hamurábi! A pesquisa sócio-jurídica na pósgraduação em direito. In: Anuário dos Cursos de Pós-Graduação em Direito, n ⒔ Recife: UFPE, p. 299-330, 2003.

PELLET, Sarah. A Ambigüidade da Noção de Terrorismo. In: Leonardo Nemer Caldeira BRANT (org.). Terrorismo e direito: os impactos do terrorismo na comunidade internacional e no Brasil. Rio de Janeiro: Forense, 2003. p. 9-20.

PIOVESAN, Flávia. Lei de anistia, sistema interamericano e o caso brasileiro. In: GOMES, Luiz Flávio; MAZZUOLI, Valério de Oliveira (orgs.). Crimes da Ditadura Militar - Uma análise à luz da jurisprudência atual da Corte Interamericana de Direitos Humanos. São Paulo: Revista dos Tribunais, 2011. p. 73-86.

PIOVESAN, Flávia. Direitos Humanos e Justiça Internacional. São Paulo: Saraiva, 2006.

PORTO, Humberto A. Sierra. La Función de la Corte Constitucional en la Protección de los Derechos de las Víctimas a la Verdad, la Justicia y la Reparación en Colombia. In: Anuario de Derecho Constitucional Latinoamericano, Ano XV. Montevideo: Konrad Adenauer Stiftung, 2009. p. 179-188.

SAMPAIO, José Adércio Leite. Constituição e Terror - Uma Visão Parcial do Fenômeno Terrorista. In: BRANT, Leonardo Nemer Caldeira (org.). Terrorismo e direito: os impactos do terrorismo na comunidade internacional e no Brasil. Rio de Janeiro: Forense, 2003. p. 151-170.

TEITEL, Ruti. Genealogía de la Justicia Transicional. Santiago: Centro de Derechos Humanos/Facultad de Derecho de la Universidad de Chile, 2003.

TRINDADE, Antonio Augusto Cançado. Direitos Humanos: Personalidade e Capacidade Jurídica Internacional do Indivíduo. In: BRANT, Leonardo Nemer Caldeira (org.). O Brasil e os Novos Desafios do Direito Internacional. Rio de Janeiro: Forense, 2004. p. 199-264.

UPRIMNY, Rodrigo; SAFFON, María Paula. Justicia Transicional y Justicia Restaurativa Tensiones y Complementaridades. 2010. Disponível em: http://www.idrc.ca/en/ev84576-201-1-DO TOPIC.html. Acesso em: 26/11/2010.

VELLOSO, Carlos Mário da Silva. A Extradição e seu Controle pelo Supremo Tribunal Federal. In: BRANT, Leonardo Nemer Caldeira (org.). Terrorismo e direito: os impactos do terrorismo na comunidade internacional e no Brasil. Rio de Janeiro: Forense, 2003. p. 115150. 
WARAT, Luis Alberto. Introdução geral ao Direito I - Interpretação da lei: temas para uma reformulação. Porto Alegre: Sergio Antonio Fabris, 1994.

WEICHERT, Marlon Alberto; FÁVERO, Eugênia Augusta Gonzaga Fávero. A Responsabilidade por Crimes Contra a Humanidade Cometidos Durante a Ditadura Militar. In: SOUZA NETO, Cláudio Pereira de; SARMENTO, Daniel; BINENBOJM, Gustavo (orgs.). Vinte Anos da Constituição Federal de 1988. Rio de Janeiro: Lumen Juris, 2009. p. 511568.

ZAFFARONI, Eugénio Raúl. El crimen de Estado como objeto de la criminología. In: RAMÍREZ, Sergio García; MARISCAL, Olga Islas de González (orgs.). Panorama internacional sobre justicia penal. Política criminal, derecho penal y criminologia. Culturas y Sistemas Jurídicos Comparados - Séptimas Jornadas Penales. México: UNAM, 2007. p. 19-34.

ZANUZO, Vanívia Roggia. Direitos Humanos, Justiça Transicional e Leis de Anistia. Coimbra: Faculdade de Direito da Universidade de Coimbra (Dissertação de Mestrado), 2009. 